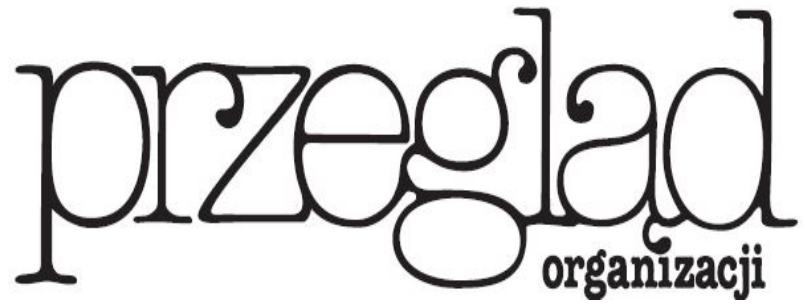

Miesięcznik TNOiK

Założył Karol Adamiecki w 1926 r.

\title{
SAMOORGANIZUJACE SIĘ ZESPOŁY PROJEKTOWE - DOTYCHCZASOWE ROZWAŻANIA I NOWE PROPOZYCJE BADAWCZE
}

https://doi.org/10.33141/po.2019.05.06

\section{Alina Kozarkiewicz, Jakub Perlak}

\section{Wprowadzenie}

$\mathbf{Z}$ arządzanie projektami od kilku dekad cieszy się niesłabnącym zainteresowaniem ze strony badaczy akademickich i praktyków. Jego rozwój oznacza z jednej strony nowe i oryginalne koncepcje teoretyczne, $z$ drugiej - nowe metodyki i narzędzia wspomagające realizację projektów czy zapewniające lepszą skuteczność w spełnianiu oczekiwań klientów i odbiorców produktów. Ważnym obszarem zarządzania projektami i zespołami projektowymi jest tak zwane zarządzanie zwinne (agile). Zasady i metody podejścia zwinnego coraz szybciej przenikają z sektora IT zarówno do sektorów kreatywnych, jak i bardzo tradycyjnych, takich jak np. motoryzacja czy automatyka przemysłowa.

W bardzo wielu publikacjach i na licznych stronach internetowych można odnaleźć prezentację ewolucji zwinnego zarządzania projektami, historię powstania Agile Manifesto (Highsmith, Fowler, 2001), przytaczane są jego zasady i omawiane efekty w postaci rozwoju tzw. metodyk (podejść) zwinnych. Zwinne zespoły projektowe charakteryzuje orientacja na interakcje międzyludzkie, odpowiednio działające oprogramowanie, współpraca z klientem i gotowość reagowania na zmiany. Hasłem, które bardzo często pojawia się w kontekście zwinnego zarządzania, jest samoorganizacja. Analizując podręczniki o zwinnych metodykach lub zespołach projektowych, można jednak
Przegląd Organizacji, Nr 5 (952), 2019, ss. 39-47 www.przegladorganizacji.pl OTowarzystwo Naukowe Organizacji i Kierownictwa (TNOiK) zauważyć, że pojęcie samoorganizacji traktowane jest jako oczywiste w interpretacji - tautologicznie wyjaśnia się, że samoorganizujący się zespół to taki, w którym członkowie sami organizują swoją pracę. Czy jest to jednak pełna definicja tego pojęcia? Czy samoorganizujący się zespół to wyłączna cecha zwinnego zarządzania projektami wytwarzania oprogramowania? Podobne pytanie można zaadresować w odniesieniu do badań naukowych: jaki jest zakres badań naukowych nad samoorganizacją zespołów? Czy pojęcie samoorganizacji jest synonimiczne $\mathrm{z}$ takimi jak autonomia lub samozarządzanie?

Przedstawione powyżej wątpliwości stały się najważniejszym źródłem motywacji do podjęcia eksploracji tematyki samoorganizacji. Problematyka była badana zarówno w szerszym kontekście nauk o zarządzaniu, jak i wąskim - samoorganizacji zwinnych zespołów projektowych. Ponieważ celem tych badań jest poszukiwanie odpowiedzi na pytanie badawcze dotyczące stanu badań nad zjawiskiem samoorganizacji zespołów, wybraną metodą prowadzenia badań był systematyczny przegląd literatury.

Artykuł obejmuje dwie zasadnicze części: w pierwszej $\mathrm{z}$ nich, na podstawie tradycyjnego przeglądu literatury nakreślono syntetycznie najważniejsze pojęcia i koncepcje związane $\mathrm{z}$ samoorganizacją, $\mathrm{w}$ drugiej natomiast zaprezentowano wyniki systematycznego przeglądu literatury 
obejmujące badania bibliometryczne, analizę tematyki opublikowanych prac oraz proponowanych przez autorów kolejnych propozycji badawczych.

\section{Badania nad samoorganizacją w naukach o zarządzaniu}

B adania nad organizacją zespołów, strukturami organizacyjnymi i ich wpływem na efektywność organizacji mają bogatą historię. W literaturze dyskusje o strukturach i ich tworzeniu rozpoczyna często nawiązanie do prac M. Webera i jego uznawanych za klasyczne tekstów na temat biurokracji (Sine i in., 2006). Bardzo ważną rolę $\mathrm{w}$ rozwoju nurtu badań organizacyjnych odegrała koncepcja T. Burnsa i G.M. Stalkera (1961). Badając relacje między formalizacją struktury organizacyjnej a wynikami organizacji, autorzy udowodnili, że organizacje o strukturach organicznych, czyli luźno powiązanych sieci współpracowników, lepiej adaptują się do dynamicznego otoczenia. Organizacje o strukturach mechanistycznych, w których zadania są przydzielane specjalistom $\mathrm{w}$ ramach zdefiniowanej hierarchii, są bardziej odpowiednie w warunkach statycznego, mało zmiennego środowiska. Współczesne organizacje, funkcjonujące $\mathrm{w}$ warunkach niepewności, imperatywu innowacyjności i presji konkurencyjnej, bardzo często bazują na zasadach typowych dla struktur organicznych. Co więcej, obecnie szczególnego znaczenia nabierają autonomia i samoorganizacja.

Termin „samoorganizacja” (https://sjp.pwn.pl/szukaj/ samoorganizacja.html) pojawia się $\mathrm{w}$ nauce $\mathrm{w}$ bardzo wielu kontekstach, zjawisko to dotyczy procesów biologicznych, chemicznych, optymalizacji matematycznej, a w naukach społecznych jest łączone m.in. z samorządnością czy samopomocą. W przypadku nauk o zarządzaniu historia badań nad zjawiskiem samoorganizacji liczy już również wiele dekad. Na przykład można odnaleźć wyniki badań naukowych nad zjawiskiem samoorganizacji - autonomii zespołów górników w kopalniach angielskich - analizowanej z perspektywy systemów techniczno-społecznych w pracach z lat 50. (Hoda, Murugesan, 2016). Warto zwrócić uwagę, że temat podejmowali też słynni twórcy teorii organizacji, np. G. Morgan w swoich bestselerowych Obrazach organizacji (1986) nawiązuje do samoorganizacji zespołów - organizacji polegającej na akceptacji dla redundancji funkcji, minimalnej zewnętrznej specyfikacji zadań, przekazywania ich do samodzielnej realizacji zespołom, wymaganej różnorodności umiejętności w zespole. H. Takeuchi i I. Nonaka (1986) w swoich cytowanych do dzisiaj pracach analizowali warunki samoorganizacji zespołów: autonomię, międzyfunkcjonalność i ciągłe samodoskonalenie. W kolejnych latach rozwoju nauk o zarządzaniu - w latach 90., samoorganizacja pojawia się jako cecha złożonych systemów adaptacyjnych (complex adaptive systems). Samoorganizacja, zgodnie $\mathrm{z}$ podejściem systemowym, jest definiowana jako proces zachodzący $\mathrm{w}$ systemach kompleksowych, w którym wyłaniają się wewnętrznie struktury, wzorce i własności, bez zewnętrznego narzu- cania rozwiązań (Goldstein, 1994 za: Werder, Maedche, 2018). Ostatnie lata, czyli wspomniany we wprowadzeniu rozwój zwinnego zarządzania projektami, związany z eksplozją IT i projektów wytwarzania oprogramowania, przyniósł kolejną falę zainteresowań autonomią zespołów i zjawiskiem samoorganizacji.

Samoorganizacja jest powiązana $\mathrm{z}$ takimi pojęciami, jak: emergencja, np. emergencja przywództwa (Hoda i in., 2010), autonomia, czyli wolność wyborów dokonywanych przez zespół (Dyer, Ericksen, 2005; Moe i in. 2010; Langfred, 2004), upełnomocnienie, czyli partycypacja w podejmowaniu decyzji (Sheffield, Lemétayer, 2013; Srivastava, Jain, 2017), dynamika lokalna, czyli zmiany w relacjach na poziomie zespołu, a także elastyczność i adaptacja (Werder, Maedche, 2018).

\section{Samoorganizacja i samozarządzanie w zwinnych zespołach}

Wytwarzanie oprogramowania od wielu lat spotyka się z licznymi wyzwaniami - rosnącymi i trudnymi do przewidzenia oczekiwaniami klientów lub odbiorców produktów, nowymi technologiami informatycznymi, często o charakterze dysruptywnym czy wreszcie $\mathrm{z}$ rosnącą konkurencją. Odpowiedzią na wspomniane wyzwania stał się rozwój koncepcji bazujących na pojęciu zwinności, a w konsekwencji pojawienie się w literaturze i praktyce wytwarzania oprogramowania takich pojęć, jak: zwinne zarządzanie projektami, metodyki (metody) zwinne, praktyki zwinne lub zwinne zespoły.

Przyspieszenie rozwoju podejścia zwinnego stało się efektem popularyzacji wspomnianego we wprowadzeniu Manifestu zwinności i jego zasad (Highsmith, Fowler, 2001). Jedną z tych ważnych zasad jest zasada 11: „najlepsze architektury, wymagania i projekty wyłaniają się z samoorganizujących się zespołów" (Highsmith, Fowler, 2001). Według zwolenników podejścia zwinnego, narzucanie architektury systemu informatycznego, narzędzi pracy lub współpracy, zadań, sposobów pracy może się spotykać z niezadowoleniem zespołu, dlatego też lepszą opcją niż odgórne (zewnętrzne) narzucanie rozwiązań jest taka sytuacja, kiedy zespół sam podejmuje decyzje i działania. Samoorganizacja jest ważnym elementem zwinności zespołu projektowego.

Samoorganizujące się zespoły w zwinnych projektach wytwarzania oprogramowania powinien cechować wysoki poziom autonomii, zaangażowania w wybór i realizację własnych zadań. Członkowie zespołu sami przyjmują określone role zespołowe, aby sprostać realizacji całego zbioru powierzonych zadań, zapewniając równowagę pomiędzy wolnością a odpowiedzialnością, specjalizacją a międzyfunkcjonalnością, ciągłym samouczeniem się a spełnieniem presji danej iteracji (Hoda, Murugesan, 2016).

Samoorganizacja zespołu polega na stworzeniu zespołu z osób, które same zarządzają swoim nakładem pracy, zmieniają zadania na podstawie potrzeb i najlepszego dopasowania, biorą udział w podejmowaniu decyzji. Zespół w takich warunkach powinien mieć wspólny cel (koncen- 
trację na zadaniu), zaufanie, respekt i zdolność do reorganizacji w miarę pojawiania się nowych wyzwań. Sukces samoorganizacji związany jest w międzyfunkcjonalnością, specjalizacją uczestników, ich różnymi umiejętnościami. Koordynacja zespołu wymaga samokoordynacji dzięki codziennym spotkaniom i wymianie informacji. Zespół cechuje wspólne zespołowe podejście do pojawiających się problemów i wspólna odpowiedzialność. Samoorganizujące się zespoły działają poprzez istnienie nieformalnych ról pełnionych przez uczestników zespołów - mentor, koordynator, translator, mistrz (czampion), promotor i terminator, pozwalających na istnienie procesów samoorganizacji (Hoda i in., 2010).

Samoorganizujące się zespoły nie są zespołami bez lidera (przywództwa), przywództwo jest jednak adaptacyjne, zapewniające feedback i nadające kierunek. Przywódca jest odpowiedzialny za cele (kierunek), pozyskanie zasobów i motywowanie zespołu.

Autonomia zespołu, rozumiana jako wolność co do wyboru sposobu działania i realizacji zadań, jest antecedencją samoorganizacji, nie jest jednak warunkiem wystarczającym. Autonomia może być rozpatrywana jako indywidualna na poziomie poszczególnych członków zespołu projektowego, wewnętrzna autonomia zespołowa - związana ze wspólnym, ale niezależnym zewnętrznie podejmowaniem decyzji przez zespół, zewnętrzna - związana $z$ brakiem wpływu zewnętrznego na wewnętrzne sprawy zespołu.

Terminem podobnym do samoorganizacji i autonomii jest pojęcie samozarządzanie. Czasami oba terminy stosowane są przez autorów we wręcz analogicznych kontekstach (Srivastava, Jain, 2017). Samozarządzanie jest bowiem również związane $\mathrm{z}$ samodzielnym podejmowaniem decyzji przez zespół. Samozarządzający się zespół jest rozumiany jako grupa powiązanych relacjami niezależnych osób, które mogą same regulować działalność dotyczącą relatywnie kompleksowych zadań (Langfred, 2004). Sens samozarządzania polega zatem na dowolności, swobodzie wyboru sposobu realizacji zadania i alokowania zadań pomiędzy uczestników. Zespół staje się zaangażowany w takie działania zarządcze jak planowanie, estymacja (czasów, zasobów) oraz ocena stopnia spełnienia wymagań (Hoda i in., 2010).

\section{Przebieg badań własnych - procedura selekcji publikacji}

ak wspomniano we wprowadzeniu, celem tego artykułu jest poznanie obecnego stanu wiedzy na temat samoorganizacji zwinnych zespołów projektowych, a przede wszystkim identyfikacja głównych trendów tematycznych, obszarów badawczych oraz rekomendacji odnośnie do dalszych badań. Metodą badawczą użytą $\mathrm{w}$ artykule jest systematyczny przegląd literatury. Jest to metoda określona ścisłą procedurą badawczą, oparta na wykorzystaniu metod ilościowych. Odróżnia ją to od klasycznego (tradycyjnego) przeglądu literatury, który często bywa subiektywny i niekompletny (Czakon, 2016). Dodatkową zaletą jest procedura badawcza obarczona rygorem metodycznym, co znacznie ułatwia późniejszą replikację.

Najczęściej systematyczny przegląd literatury składa się z następujących etapów: postawienie celu badawczego, wyróżnienie i selekcja literatury, analiza bibliometryczna oraz raport z badań (Czakon, 2016). Badanie prezentowane w tej pracy oparto na tak zarysowanym postępowaniu badawczym. Przebieg badania własnego został pokazany na rysunku 1.

Badania zostały przeprowadzone w styczniu 2019 r. Zdecydowano się na wybór trzech najpopularniejszych baz danych zawierających czasopisma naukowe: Science Direct (Elsevier), Emerald Insight i Wiley Online $\mathrm{Pu}$ blishing. Dodatkowo, w celu ustalenia przybliżonej liczby cytowań artykułów posłużono się bazą Google Scholar. Zdecydowano się na wybór anglojęzycznych baz czasopism ze względu na łatwy dostęp do pełnych tekstów artykułów oraz pełnych lub rozszerzonych abstraktów.

Selekcję publikacji podzielono na dwa główne etapy określone symbolami A i B. W ramach etapu A przeszukiwano bazy szeroko zdefiniowanymi kryteriami: samoorganizacja, czyli self-organization i samozarządzanie, czyli self-management, a następnie zawężono poszukiwania do zagadnień związanych z zespołami (self-organizing teams i self-managing teams). W kolejnym etapie B dodano hasło związane ze zwinnym zarządzaniem projektami, czyli agile. $\mathrm{W}$ ostatnim kroku wyselekcjonowano artykuły do dalszej szczegółowej analizy bibliometrycznej i tematycznej.

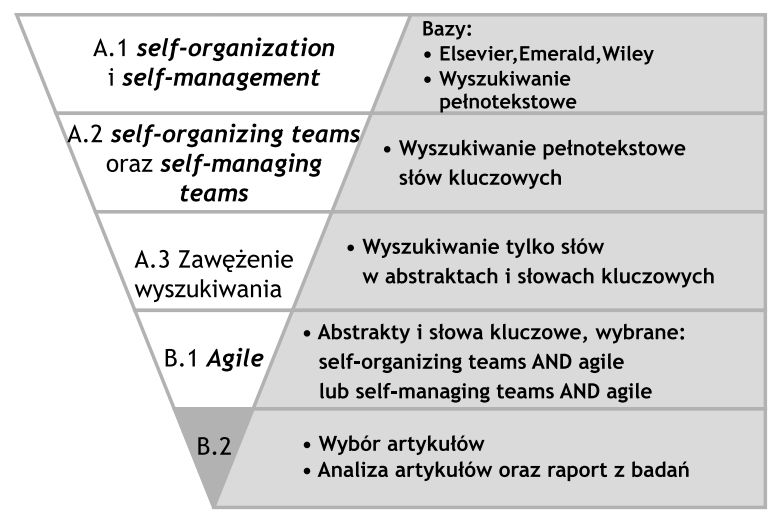

\begin{tabular}{|c|}
\hline Elsevier \\
\hline 871273 \\
\hline 160230 \\
\hline 287 \\
\hline 9 \\
\hline 7 \\
\hline
\end{tabular}

\begin{tabular}{|c|}
\hline Emerald \\
\hline 208461 \\
\hline 91095 \\
\hline 731 \\
\hline 22 \\
\hline 5 \\
\hline
\end{tabular}

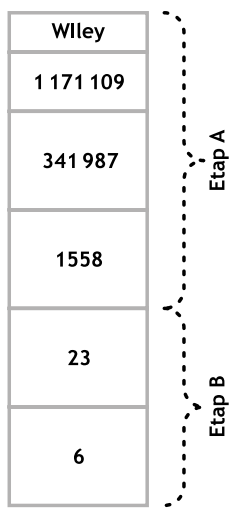

Rys. 1. Procedura badania wtasnego

Źródto: opracowanie wtasne 
Zaprezentowana syntetycznie procedura selekcji publikacji naukowych obejmowała etapy szczegółowe. W pierwszym kroku (A.1) etapu A wyszukano teksty naukowe zawierające słowa (kryteria) związane z samoorganizacją self-organization i samozarządzaniem self-management $\mathrm{i}$ - zgodnie $\mathrm{z}$ oczekiwaniami - w wyniku takich przeszukiwań uzyskano bardzo dużą liczbę publikacji. Samoorganizacja dotyczy bowiem systemów złożonych i jest wykorzystywana w różnych naukach jako model wyjaśniania różnorodnych zjawisk (Werder, Maedche, 2018). W procesie badawczym należało zatem ograniczać wyselekcjonowany zbiór i systematycznie zmniejszać liczbę prac do dalszej analizy. W następnym kroku (A.2) kryteria przeszukiwań uszczegółowiono przez dodanie hasła związanego z zespołami: self-organizing teams i self-managing teams. Kolejnym krokiem (A.3) była redukcja wyników tylko do tych publikacji, w których hasła (kryteria selekcji) występowały $\mathrm{w}$ abstrakcie lub w słowach kluczowych artykułu, co zredukowało znacząco liczbę prac z kilkudziesięciu tysięcy do kilkuset pozycji.

$\mathrm{Na}$ wykresach na rysunku 2 zaprezentowano syntetycznie wyniki kroku A.3 obejmujące okres od 1995 do 2018 roku. Jak wynika $\mathrm{z}$ wykresów, zauważalny jest trend wzrostowy - rośnie zainteresowanie badaczy problematyką samoorganizacji i samozarządzania w zespołach. Dodatkowo, na wykresach zaznaczono intencjonalnie datę publikacji Agile Manifesto (Highsmith, Fowler, 2001), co ma na celu sprawdzenie wpływu tego istotnego dla zarządzania zwinnego momentu na zainteresowania naukowe dotyczące samoorganizacji.

W etapie drugim postępowania badawczego (B) dodano do wyszukiwania hasło (kryterium) agile. Jak założono, zmniejszyło to znacznie liczbę selekcjonowanych prac, w efekcie uzyskano od kilku do kilkunastu artykułów, zależnie od bazy. Zawężono też wyszukiwanie do abstraktów i słów kluczowych (B.1). Ostatnim krokiem (B. 2) była finalna selekcja artykułów do szczegółowej analizy bibliograficznej. Przeanalizowano otrzymany zbiór artykułów, odrzucono artykuły powtarzające się oraz te, które - jak się okazało - miały zbyt luźny związek z tematyką prowadzonych badań. Efektem finalnym selekcji była lista 18 wyodrębnionych artykułów. Listę tych artykułów uzupełniono o 9 dodatkowych publikacji, które są rezultatem przeglądu bibliografii artykułów z otrzymanej listy.
Ostatecznie do analizy bibliograficznej łącznie wybrano 27 artykułów.

\section{Analiza bibliometryczna}

$\mathbf{N}$ astępnym krokiem w systematycznym przeglądzie literatury jest analiza bibliometryczna (Czakon, 2016). $\mathrm{Na}$ tym etapie postępowania badawczego przeanalizowano takie zagadnienia, jak: miejsca publikacji, czyli czasopisma naukowe, w których ukazały się wyselekcjonowane prace, metody badawcze stanowiące podstawę wyników prezentowanych $\mathrm{w}$ tych pracach, liczbę cytowań, słowa kluczowe, słowa użyte w abstraktach. W rezultacie analizy bibliometrycznej dokonano również pogrupowania artykułów ze względu na poruszany temat.

Zgodnie $\mathrm{z}$ przewidywaniami, artykuły publikowane były $\mathrm{z} \mathrm{w}$ różnych czasopismach naukowych, ale większość, tzn. 54\% (15) artykułów z wybranej listy zostało opublikowanych w czasopismach naukowych związanych z obszarem technologii informatycznych (IT). Najwięcej, bo po 3 publikacje, ukazały się w Journal of Systems and Software i Information and Software Technology. Potwierdza to rodowód podejścia zwinnego, które zostało zapoczątkowane $\mathrm{w}$ celu udoskonalenia wytwarzania oprogramowania (Highsmith, Fowler, 2001). Większość artykułów odwołuje się do zespołów programistycznych (Hoda, Murugesan, 2016). Wyselekcjonowane artykuły były publikowane w okresie od 2000 do 2018 roku, przy czym tylko jeden artykuł pochodził sprzed Agile Manifesto i dotyczył autonomii zespołów samozarządzających się (Langfred, 2000).

Kolejnym krokiem była analiza i porównanie zastosowanych metod badawczych. Jak wynika $\mathrm{z}$ tego etapu analiz, dominującą metodą badań (a właściwie: strategią badawczą) okazało się studium przypadku. To podejście badawcze dotyczyło 8 artykułów (ok. 30\% całej bazy). Kolejnymi metodami stosowanymi w badaniach nad samoorganizacją były wywiady (15\%), teoria ugruntowana, badania sondażowe (ankiety) i przeglądy literatury. Stosowano także metody mieszane.

W kolejnym kroku badań bibliometrycznych skoncentrowano się na problemie cytowalności i częstości cytowań wybranych prac. W tym celu posłużono się popularnym narzędziem prezentującym cytowania poszczególnych

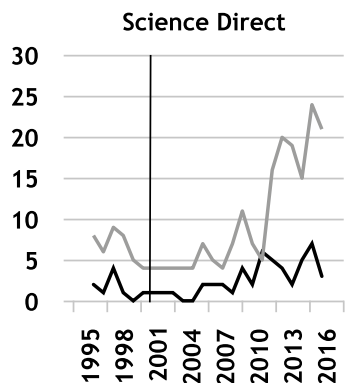

- Samoorganizacja

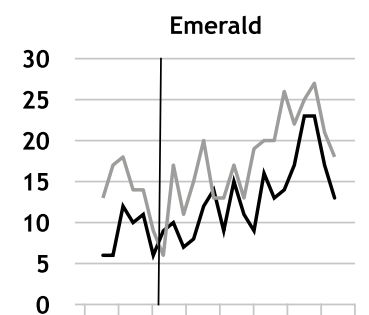

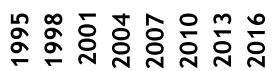

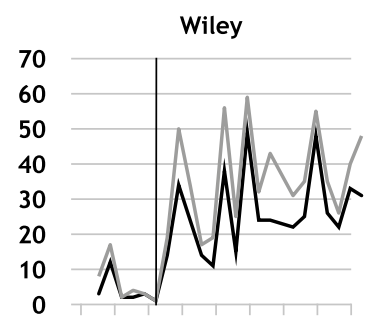

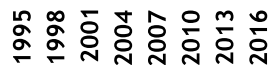

- Samozarządzanie

Rys. 2. Wykresy liniowe z liczbą publikacji artykutów w bazach

Źródło: opracowanie własne 
publikacji naukowych, czyli Google Scholar. W tabeli 2 przedstawiono częstotliwość cytowań najpopularniejszych - zgodnie z tym kryterium - artykułów.

Jak można było założyć, najczęściej cytowane prace to prace opublikowane w amerykańskim piśmie Academy of Management Journal. Liczba cytowań jest zapewne efektem prestiżu i rangi tego pisma. Co interesujące, wśród wyselekcjonowanych prac do najczęściej cytowanych należą prace dotyczące problematyki samozarządzania.

W ramach dalszej analizy zbioru artykułów skupiono uwagę na słowach kluczowych. Wykorzystano analizę frekwencyjności słów kluczowych metodą chmury słów (rys. 3). Jak wynika z rysunku, większość artykułów związana jest $\mathrm{z}$ podejściem zwinnym agile oraz tematyką zespołów programistycznych (software, developer i team).

Jako uzupełnienie analizy zawartości tekstu (słów) dokonanej techniką chmury słów była analiza grupowania słów (rys. 3). W tym celu wykorzystano narzędzie VOSviewer, które umożliwia tworzenie wizualizacji opartych o grupowanie słów. Zilustrowano pojawienie się słowa przynajmniej 7 razy w abstraktach wyłonionych artykułów. Dodatkowo, aby dostrzec najistotniejsze zagadnienia, pokazano na wizualizacji nie więcej niż 17 grup przy wykluczeniu słów typu: paper, data, study i author.

$\mathrm{W}$ efekcie tego etapu badań pojawiły się tematy (zagadnienia), które będą dalej analizowane w sposób szczegółowy. Uzyskano między innymi takie grupy tematyczne, jak: autonomia, praktyki, wpływ na wyniki czy wyzwania.

\section{Analiza tematyki artykułów}

W efekcie ilościowych analiz słów, a także analiz zawartości poszczególnych wyselekcjonowanych publikacji naukowych dokonano ich klasyfikacji w określone grupy tematyczne (tab. 2). Z oczywistych względów uzyskanie rozłącznych i jednoznacznych grup publikacji nie było możliwe, np. autonomia zespołów samozarządzających się stanowi antecedencję samoorganizacji, ale też może być barierą dla zespołu (Langfred, 2004).

Pierwsza $\mathrm{z}$ wyodrębnionych grup artykułów, tzn. podejście systemowe, traktuje zespół projektowy jako złożony system adaptacyjny (complex adaptive system). L. Dyer i J. Ericksen (2005) sugerują powszechność fenomenu samoorganizacji w systemach społecznych, zaznaczając jednocześnie, że spoiwem dla samoorganizacji jest zaufanie. Podkreślają, że warunkiem samoorganizacji jest autonomia, postrzegana przez autorów jako brak procesów zarządzania. Autorzy wymieniają również reguły sprzyjające samoorganizacji zespołów: płynna organizacja pracy, brak hierarchii, dobre relacje, otwartość i akceptacja dla popełniania błędów. Z kolei M. Browaeys i S. Fisser (2012) wskazują na ciągłą interakcję samoorganizującego się zespołu - postrzeganego jako system - $\mathrm{z}$ otoczeniem tego systemu. Nowatorskim pomysłem jest potraktowanie samoorganizującego się zespołu jako takiego systemu, który integruje dwa podejścia do wytwarzania oprogramowania - zwinne (agile) oraz szczupłe (lean).

Tabela 1. Lista najczęściej cytowanych artykułów z wyselekcjonowanego zbioru

\begin{tabular}{|l|l|}
\hline \multicolumn{1}{|c|}{ Publikacja } & Liczba cytowań \\
\hline $\begin{array}{l}\text { Langfred C.W. (2004), Too Much of a Good Thing? Negative Effects of High Trust and Individual Autonomy in Self-managing } \\
\text { Teams, „Academy of Management Journal”, 47(3), pp. 385-399 }\end{array}$ & 753 \\
\hline $\begin{array}{l}\text { Druskat V.U., Wheeler J.V. (2003), Managing from the Boundary: The Effective Leadership of Self-managing Work Teams, } \\
\text { „Academy of Management Journal”, 46(4), pp. 435-457 }\end{array}$ & 528 \\
\hline $\begin{array}{l}\text { Moe N.B., Dingsøyr T., Dybå T. (2010), A Teamwork Model for Understanding an Agile Team: A Case Study of a Scrum } \\
\text { Projformation and Software Technology”, 52(5), pp. 480-491 } \\
\text { Organizational Behavior”, 21, pp. 563-585 }\end{array}$ & 370 \\
\hline $\begin{array}{l}\text { Inayat I., Salim S.S., Marczak S., Daneva M., Shamshirband S. (2015), A Systematic Literature Review on Agile Requirements } \\
\text { Engineering Practices and Challenges, „Computers in Human Behavior”, 51, pp. 915-929 }\end{array}$ & 327 \\
\hline
\end{tabular}

Źródło: opracowanie własne
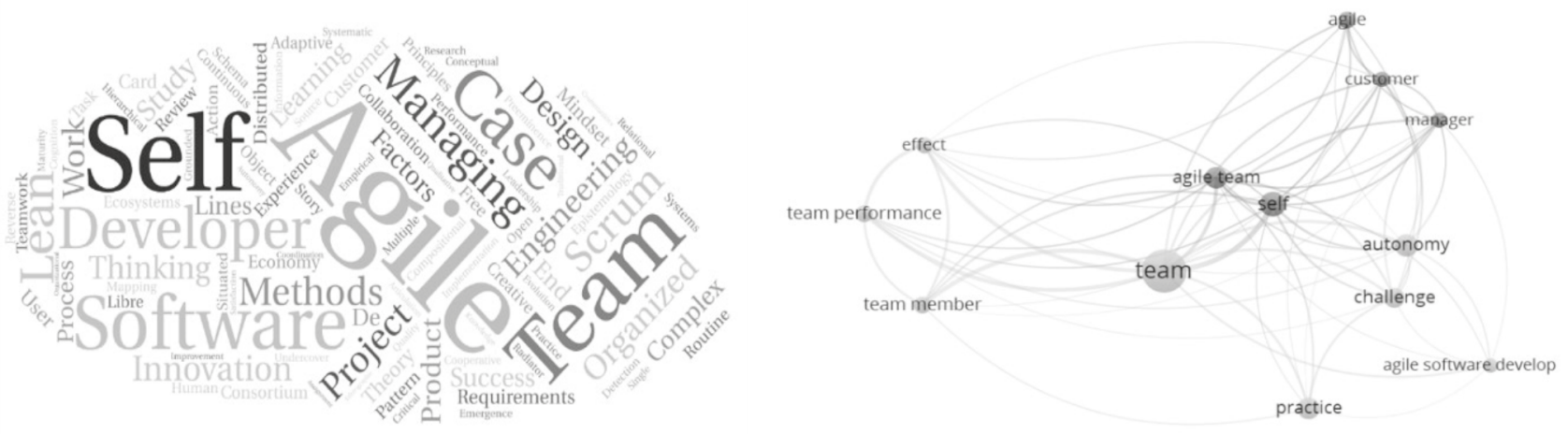

Rys. 3. Chmura stów kluczowych i wizualizacja grupowania stów Źródto: opracowanie własne 
Tabela 2. Grupy tematyczne analizowanych artykułów

\begin{tabular}{|c|c|c|}
\hline Grupa tematyczna & Liczba artykułów & Artykuły \\
\hline Podejście systemowe & 3 & Dyer, Ericksen (2005), Werder, Maedche (2018) \\
\hline Procesy i role & 5 & Langfred (2000), Hoda i in. (2010), Moe i in. (2010), Fontana i in. (2014) \\
\hline Praktyki zwinne & 6 & $\begin{array}{l}\text { Crowston i in. (2007), Jalali, Wohlin (2014), Inayat i in. (2015), Ferreira i in. (2016), } \\
\text { Annosi i in. (2018) }\end{array}$ \\
\hline Przywództwo & 2 & Druskat, Wheeler (2003), Srivastava, Jain (2017) \\
\hline Rezultaty (efekty) & 3 & Sheffield, Lemétayer (2013), Lindsjørn i in. (2016) \\
\hline Bariery i wyzwania & 6 & Bosch, Bosch-Sijtsema (2011), Hoda, Murugesan (2016), Annosi i in. ( 2016), Langfred (2004) \\
\hline
\end{tabular}

Źródło: opracowanie własne

K. Werder i A. Maedche (2018) uważają również, że autonomia stanowi warunek konieczny dla pojawienia się samoorganizacji. Dyskutując o zespołach projektowych jako złożonych systemach adaptacyjnych, wyodrębniają trzy podsystemy (poziomy): system lokalny, globalny oraz kontekstowy. Podkreślają, że zależnie od analizowanego poziomu inne czynniki są ważne dla samoorganizacji, np. dla podsystemu lokalnego będzie to jasność celów, a dla poziomu kontekstowego - wsparcie menedżerskie.

Do kolejnej grupy prac naukowych nazwanej wstępnie "procesy i role" przypisano te artykuły, które traktują szeroko o procesach zachodzących w zespołach projektowych, w tym o procesach tworzenia się ról nieformalnych. Znalazły się tu rozważania o wspomnianej już autonomii, która stanowi warunek niezbędny do procesu samoorganizacji. Potwierdzają to m.in. badania C.W. Langfreda (2000) dotyczące autonomii indywidualnej i zespołowej. Z kolei R. Hoda, J. Noble i S. Marshall (2010) próbują odpowiedzieć na pytania dotyczące tego, jak dochodzi do samoorganizacji zespołów projektowych. W swojej propozycji sugerują, że w zwinnych zespołach członkowie przyjmują nieformalne role (jedną lub kilka naraz), które sprzyjają samoorganizacji. Autorzy wyróżniają sześć ról: mentor, koordynator, tłumacz, champion, promotor i terminator. Autorzy pokazują, że podczas procesu formowania się zespołu niezbędna jest początkowo rola mentora oraz mistrza (championa) lub promotora, posiadających autorytet $\mathrm{w}$ organizacji. Inny akcent na procesy samoorganizacji prezentują autorzy N.B. Moe i inni (2010), podkreślając, że proces zmiany zespołów $\mathrm{z}$ tradycyjnych (sterowanych) ku samozarządzającym wymaga zmiany myślenia nie tylko w przypadku członków zespołu, ale też menedżerów. Kluczowymi elementami w tej zmianie są: zaufanie, klimat w zespole i wspólny model mentalny podzielany wśród członków zespołu. Autorzy podkreślają też, że składowe ważne $\mathrm{Z}$ punktu widzenia procesu samoorganizacji to: pętla informacji zwrotnej, monitorowanie pracy własnej oraz zastępowalność zadaniowa członków zespołu. Innym zagadnieniem zajęli się R.M. Fontana i inni (2014), którzy zwracają uwagę na dojrzałość procesów w zespołach zwinnych. Wymykają się one tradycyjnym modelom dojrzałości. Autorzy sugerują, że o dojrzałości procesów samoorganizu- jącego się zespołu świadczą m.in. zdolność do współpracy, efektywnej komunikacji i dzielenia się wiedzą.

Kolejną wyodrębnioną grupą tematyczną w rozważaniach o samoorganizacji są praktyki zwinne. To bardzo szerokie pojęcie, ale mieści ono w sobie czynności wykonywane przez samoorganizujące się zespoły projektowe, między innymi takie jak: podział pracy, uczenie się, współpraca, komunikacja. W badaniach nad zespołami samoorganizującymi się w projektach typu open source (niekomercyjny charakter projektu programistycznego) K. Crowston i inni (2007) dostrzegli, że najczęściej pojawiające się praktyki zespołowe to samodzielne przypisywanie się do zadań, a także wspólne szacowanie i planowanie pracy. Kolejną listę praktyk zaproponowali m.in. S. Jalali i C. Wohlin (2014) - w badaniach wyróżniają częstą i stałą współpracę z klientem, a także pracę w małym zespole, skupionym w jednym miejscu. I. Inayat i inni (2015) prezentują znaczenie takich praktyk, jak częsta komunikacja twarzą w twarz oraz wspólna praca nad zadaniami projektowymi. Wskazane praktyki, jako praktyki istotne, potwierdzają J. Ferreira, H. Sharp i R. Hugh (2016), argumentując, że zwinne zespoły opierają się na współpracy i są otwarte na nawiązywanie kontaktów $\mathrm{z}$ pracownikami $\mathrm{z}$ całej organizacji. Inną ważną praktykę związaną z uczeniem się w zespołach zwinnych, omawiają M.C. Annosi i inni (2018), podkreślając rolę częstych informacji zwrotnych na temat rutynowych praktyk, będących ważnym źródłem uczenia się w ramach zespołu.

Temat przywództwa stanowi kolejną grupę artykułów wyodrębnionych podczas badania. V.U. Druskat i J.V. Wheeler (2003) przedstawiają charakterystykę menedżera pracującego z samozarządzającym się zespołem. Rola ta jest skupiona na budowaniu relacji, dostarczaniu informacji oraz na wzmacnianiu i przekazywaniu odpowiedzialności do zespołów (ment). Autorzy sygnalizują również, że zespoły samozarządzające wydają się bardziej złożone w oczach menedżerów, gdyż brakuje im systemów kontroli nad takim zespołami. W podobnym tonie o wspierającej roli lidera w zespołach zwinnych piszą P. Srivastava i S. Jain (2017). Wraz z popularyzacją metod zwinnych rola lidera zespolów się zmienia. Autorzy opisują lidera jako osobę dbającą o zespół i reagującą w wyjątkowych sytuacjach, przekazując decyzyjność do samoorganizujących się zespołów. 
Następną grupą tematyczną poruszaną w badaniach nad samoorganizacją w zespołach zwinnych są rezultaty (efekty) pracy takich zespołów. Badania J. Sheffield i J. Lemétayer (2013) wskazują, że zespoły zwinne, które odnoszą sukces projektowy, pracują w odpowiednim środowisku, w którym kultura organizacyjna wspiera samoorganizację, a także posiadają upełnomocnienie i decyzyjność. Z kolei F. Fagerhom i inni (2015) wyodrębnili aż 33 kategorie wskaźników wydajności zespołowej, wskazując jednocześnie, że wskaźniki wydajności dla zespołów mogą się różnić zależnie od organizacji, czy szerzej - od kontekstu, w jakim pracuje zespół. Jednak autorzy sugerują istotność roli, jaką pełnią niezależne wskaźniki związane są z miękkimi elementami pracy, takimi jak: komunikacja, morale w zespole, identyfikacja z zespołem oraz wartości. Uzupełnieniem tych informacji mogą być badania Y. Lindsjørn i innych (2016) dotyczące wpływu jakości pracy (teamwork quality) w zespole na jego wydajność. Autorzy stwierdzają brak znaczących różnic między zwinnymi zespołami projektowymi a tradycyjnymi, zorientowanymi na plan projektu. Ten wniosek, jak się wydaje, wymaga jednak porównań i dyskusji.

Grupa tematyczna dotycząca barier i wyzwań skupia artykuły, które analizują potencjalne problemy zespołów samoorganizujących się. Jak pokazuje przegląd artykułów, lista barier, wyzwań czy problemów z samoorganizacją jest dość znacząca. C.W. Langfred (2004) sugeruje ciekawy paradoks $-\mathrm{z}$ jednej strony autonomia jest warunkiem i antecedencją samoorganizacji zespołu, jednak $z$ drugiej strony zbyt duża autonomia na poziomie indywidualnym członków zespołu może negatywnie odbić się na wydajności zespołu jako całości. W kolejnym artykule N.B. Moe i inni (2010) uzupełniają listę barier o problemy z orientacją na cel zespołu, wyzwania związane z przywództwem i koordynacją prac w zespole. Z kolei J. Bosch i P.M. Bosch-Sijtsema (2011) zwracają uwagę na warunki powstawania zespołu i jego rozmiar. Autorzy argumentują, że zbyt duże zespoły, które nie pracują w jednym miejscu i nie mają możliwość komunikacji twarzą w twarz, mają trudność w samoorganizacji pracy. Na inne problemy kładzie nacisk M.C. Annosi i inni (2016). Autorzy sugerują, że presja organizacyjna na utworzenie zwinnych samoorganizujących się zespołów może blokować procesy uczenia się i nie sprzyja innowacyjności w zespołach. Kompleksowe zestawienie wyzwań, które stoją przed samoorganizującymi się zespołami projektowymi przedstawili natomiast R. Hoda i L.K. Mrugesan (2016). Autorzy podzielili wyzwania na kilka najważniejszych kategorii: indywidualne, zespołowe, zadaniowe i projektowe. Do indywidualnych wyzwań zaliczyli autonomię i dobór zadań, do zespołowych - kompetencje i szacowanie pracy, w kategorii zadań wyzwaniami okazały się braki w wymaganiach oraz wzajemne zależności między zadaniami, a przypadku kategorii projektowej były to opóźnienia w wymaganiach klienta i brak wsparcia sponsora.

Jak można zauważyć, mimo dość licznych i kompleksowych badań nad barierami samoorganizacji, lista problemów związanych z procesami samoorganizacji zespołów nie jest kompletna. Można założyć, że pojawią się kolejne badania rozszerzające jej zakres.

\section{Propozycje dalszych badań}

$\mathbf{P}$ rzegląd dotychczasowych badań i analiza dyskusji prowadzonych przez ich autorów pozwala nie tylko zidentyfikować najważniejsze wątki tematyczne, ale pozwala także poznać przekonania badaczy co do możliwości kontynuacji podejmowanej problematyki, dostrzeżone przez nich kolejne luki badawcze, możliwości metodologiczne czy oczekiwania ze strony praktyki gospodarczej. Analizując opinie autorów prezentowanych powyżej publikacji naukowych, można zidentyfikować kilka interesujących propozycji co do dalszych badań nad samoorganizacją zespołów projektowych:

- kolejne badania procesów zachodzących w samoorganizujących się zespołach (Bosch, Bosch-Sijtsema, 2011), ale wzbogacenie badań o analizy wpływu większej liczby czynników (uwarunkowań) oraz analizę różnych kontekstów pracy zespołów (Annosi i in., 2018);

- wykorzystanie stosowanych strategii badawczych, takich jak kolejne pogłębione studia przypadków, w tym np. dojrzałych zespołów zwinnych (Moe i in., 2010), a także uzupełnienie podejść badawczych o badania longitudinalne (Werder, Maedche, 2018);

- rozszerzenie tematyki społecznej, w tym uzupełnienie badań o aspekty międzykulturowe (Hoda in., 2010).

Wymienione wątki wskazywane w publikacjach nie wyczerpują listy możliwości badawczych. Wskazują jedynie na różnorodność sugestii co do kierunków kontynuacji badań nad samoorganizującymi się zespołami zwinnymi. Mimo pozornej „płytkości” tematyki, ograniczeń tematycznych czy teoretycznych, analiza literatury pokazuje kolejne inspirujące możliwości badawcze. Warto podkreślić, że lista tematów pokazanych powyżej może być $\mathrm{z}$ łatwością rozszerzona o kolejne problemy i pytania badawcze. Ważną tematyką przyszłych badań wydają się analizy klasyfikacyjne dotyczące kategoryzacji (lub typologii) czynników warunkujących efektywność i skuteczność samoorganizujących się zespołów. Na obecnym etapie badań literaturowych można w zasadzie sformułować hipotezę o istnieniu uwarunkowań determinujących skuteczność samoorganizacji, czynników przyspieszających lub ułatwiających procesy (czyli istnienie katalizatorów) lub hamujących samoorganizację (istnienie inhibitorów). Ponadto w analizach klasyfikacyjnych można identyfikować czynniki uniwersalne (generyczne), takie jak presja czasu, uwarunkowania kulturowe lub demograficzne oraz czynniki specyficzne dla danego środowiska, np. wyuczone postawy programistów. Oczywiście, wskazane hipotezy wymagają kolejnych, bardziej dogłębnych badań.

Liczba publikacji dotyczących koncepcji samoorganizacji zespołów stale rośnie, co pozwala na stwierdzenie, że $\mathrm{z}$ czasem zrozumienie tej koncepcji będzie jeszcze pełniejsze.

\section{Podsumowanie}

W artykule przeanalizowano problematykę samoorganizacji i samozarządzania zespołów projektowych. Wprawdzie obie koncepcje mają swoją długą historię jako temat badań w naukach o zarządzaniu, to jednak można 
zauważyć, że rozwój podejścia zwinnego (agile), jego rosnąca popularność, a w konsekwencji - coraz bardziej powszechne zwinne zarządzanie zespołami projektowymi, stały się przyczyną powrotu do zainteresowania omawianą tematyką. Bardziej wnikliwa analiza wskazuje jednak, że trudno uznać ten zwrot za „stare wino w nowej butelce”, jest to raczej nowe spektrum, czerpiące $\mathrm{z}$ wcześniejszych dokonań, ważnych, interesujących i - przede wszystkich - aktualnych tematów.

Przeprowadzone badanie, przy wykorzystaniu metody systematycznego przeglądu literatury, pozwoliło na wyodrębnienie szeregu tematów związanych $\mathrm{z}$ samoorganizacją zespołów projektowych. Różnorodność tematyczna sięga od analiz opartych na podejściu systemowym, poprzez badania nad przywództwem, rolami w zespole, po praktyki stosowane przez zespoły projektowe. Obrazuje to bogactwo tematyczne zagadnień samoorganizacji zespołów projektowych.

Przegląd publikacji pokazał nowe propozycje badawcze, zarówno te sugerowane przez autorów prac, jak i stanowiące kontynuacje ich badań, a także istnienie nowych luk badawczych zachęcających do prowadzenia dalszych prac. Przedstawiona tematyka samoorganizacji i samozarządzania stanowi rosnący obszar zainteresowań naukowców i praktyków zarządzania, co przekłada się na rosnącą liczbę publikacji, zarówno uzupełniających, jak i stawiających nowe pytania badawcze.

\section{dr hab. inż. Alina Kozarkiewicz, prof. AGH \\ AGH w Krakowie \\ Wydział Zarządzania \\ ORCID: 0000-0002-0683-3148 \\ e-mail: akozarki@zarz.agh.edu.pl}

\section{mgr Jakub Perlak \\ AGH w Krakowie \\ Wydział Zarządzania \\ ORCID: 0000-0002-9639-9655 \\ e-mail: jakub.perlak.488@zarz.agh.edu.pl}

\section{Bibliografia}

[1] Annosi M.C., Magnusson M., Martini A., Appio F.P. (2016), Social Conduct, Learning and Innovation: An Abductive Study of the Dark Side of Agile Software Development, „Creativity and Innovation Management”, Vol. 25, No. 4, pp. 515-535.

[2] Annosi M.C., Martini A., Brunetta F., Marchegiani L. (2018), Learning in an Agile Setting: A Multilevel Research Study on the Evolution of Organizational Routines. "Journal of Business Research" (in press).

[3] Bosch J., Bosch-Sijtsema P.M. (2011), Introducing Agile Customer-centered Development in a Legacy Software Product Line, „Software: Practice and Experience”, Vol. 41, No. 8, pp. 871-882.

[4] Browaeys M.J., Fisser S. (2012), Lean and Agile: An Epistemological Reflection, „The Learning Organization”, Vol. 19, No. 3, pp. 207-218.
[5] Burns T., Stalker G.M. (1961), The Management of Innovation, Tavistock, London.

[6] Crowston K., Li Q., Wei K., Yeliz U., Howison J. (2007), Self-organization of Teams for Free/libre Open Source Software Development, „Information and Software Technology", Vol. 49, pp. 564-575.

[7] Czakon W. (2016), Metodyka systematycznego przegladu literatury, [w:] W. Czakon (red.), Podstawy metodologii badań $w$ naukach o zarzadzaniu, Wydawnictwo Nieoczywiste, Warszawa, s. 119-139.

[8] Druskat V.U., Wheeler J.V. (2003), Managing from the Boundary: The Effective Leadership of Self-managing Work Teams, „Academy of Management Journal”, Vol. 46, No. 4, pp. 435-457.

[9] Dyer L., Ericksen J. (2005), In Pursuit of Marketplace Agility: Applying Precepts of Self-organizing Systems to Optimize Human Resource Scalability, „Human Resource Management", Vol. 44, No. 2, pp. 183-188.

[10] Ferreira J., Sharp H., Hugh R. (2016), User Experience Design and Agile Development: Managing Cooperation through Articulation Work, „Journal of Theoretical and Applied Information Technology”, Vol. 93, No. 2, pp. 345-352.

[11] Fagerholm F., Ikonen M., Kettunen P., Münch J., Roto V., Abrahamsson P. (2015), Performance Alignment Work: How Software Developers Experience the Continuous Adaptation of Team Performance in Lean and Agile Environments, „Information and Software Technology", Vol. 64, pp. 132-147.

[12] Fontana R.M., Fontana I.M., Da Rosa Garbuio P.A., Reinehr S., Malucelli A. (2014), Processes versus People: How Should Agile Software Development Maturity be Defined? „Journal of Systems and Software", Vol. 97, pp. 140-155.

[13] Goldstein J. (1994), The Unshackled Organization: Facing the Challenge of Unpredictability through Spontaneous Reorganization, Productivity Press Inc., Portland.

[14] Highsmith J., Fowler M. (2001), The Agile Manifesto, „Software Development Magazine”, Vol. 9, No. 8, pp. 29-30.

[15] Hoda R., Murugesan L.K. (2016), Multi-level Agile Project Management Challenges: A Self-organizing Team Perspective, "Journal of Systems and Software Journal of Systems and Software", Vol. 117, pp. 245-257.

[16] Hoda R., Noble J., Marshall S. (2010), Organizing Self-organizing Teams, ACM/IEEE 32nd International Conference on Software Engineering, Vol. 1, pp. 285-294.

[17] Inayat I., Salim S.S., Marczak S., Daneva M., Shamshirband S. (2015), A Systematic Literature Review on Agile Requirements Engineering Practices and Challenges, „Computers in Human Behavior”, Vol. 51, pp. 915-929.

[18] Jalali S., Wohlin C. (2014), Global Software Engineering and Agile Practices: A Systematic Review, „Journal of Software: Evolution and Process", Vol. 26, No. 12, pp. 1172-1192.

[19] Langfred C.W. (2000), The Paradox of Self-management: Individual and Group Autonomy in Work Groups, „Journal of Organizational Behavior", Vol. 21, pp. 563-585.

[20] Langfred C.W. (2004), Too Much of a Good Thing? Negative Effects of High Trust and Individual Autonomy in Self-managing Teams, "Academy of Management Journal”, Vol. 47, No. 3, pp. 385-399.

[21] Lindsjørn Y., Sjøberg D.I.K., Dingsøyr T., Bergersen G.R., Dybå T. (2016), Teamwork Quality and Project Success in 
Software Development: A Survey of Agile Development Teams, „Journal of Systems and Software”, Vol. 122, pp. 274-286.

[22] Moe N.B., Dingsøyr T., Dybå T. (2010), A Teamwork Model for Understanding an Agile Team: A Case Study of a Scrum Project, „Information and Software Technology", Vol. 52, No. 5, pp. 480-491.

[23] Morgan G. (1986), Images of Organization, Sage Publications, Beverly Hills.

[24] Sheffield J., Lemétayer J. (2013), Factors Associated with the Software Development Agility of Successful Projects, "International Journal of Project Management", Vol. 31, No. 3, pp. 459-472.

[25] Sine W.D., Mitsuhashi H., Kirsch D.A. (2006), Revisiting Burns And Stalker: Formal Structure and New Venture Performance In Emerging Economic Sectors, „Academy of Management Journal”, Vol. 49, No. 1, pp. 121-132.

[26] Srivastava P., Jain S. (2017), A Leadership Framework for Distributed Self-organized Scrum Teams, „Team Performance Management", Vol. 23, No. 5-6, pp. 293-314.

[27] Takeuchi H., Nonaka I. (1986), New Product Development Game, „Harvard Business Review”, Vol. 64, pp. 137-146.

[28] Werder K., Maedche A. (2018), Explaining the Emergence of Team Agility: A Complex Adaptive Systems Perspective, „Information Technology \& People”, Vol. 31, No. 3, pp. 819-844.

\section{Self-organising Project Teams: Current Considerations and New Research Proposals}

\section{Summary}

The growing popularity of agile project management has given rise to the extension of interests in the subject of self-organisation. Self-organising project teams are characterised by a high level of autonomy as well as commitment to own tasks, and moreover, team members take roles by themselves in order to succeed with a project. The aim of the article was to explore the current state of research, perspectives and research gaps in the area of self-organising project teams. A systematic literature review (SLR) was chosen as a research method. Research demonstrated in the article resulted in identifying main theme groups of publications: system approach, process and roles, practices, leadership, results, barriers and challenges. In addition, further research proposals oriented towards better understanding of the phenomena of self-organising project teams have been examined.

\section{Keywords}

self-organization, self-management, project team, agile team 